\title{
Differences by Resistotyping Between C. albicans Strains Isolated from the Oral Cavity of HIV+ and Seronegative Patients
}

\section{Diferencias por resistotipificación entre cepas de C. albicans aisladas de la cavidad oral de pacientes VIH+ y seronegativos}

Florencio Rueda-Gordillo PhD1; Sandra Elena Hernández-Solís PhD1; Luis Alberto Gaitán-Cepeda PhD²; Luis Octavio Sánchez-Vargas PhD; Esperanza Mercedes Lama-González MDent1; María del Sagrado Corazón Rodríguez-Fernández MDent ${ }^{1}$

1. Departamento de Microbiología Oral y Biología Molecular. Facultad de Odontología, Universidad Autónoma de Yucatán. Mérida, Yucatán; México.

2. Laboratorio de Patología Clínica y Experimental, División de Estudios de Postgrado e Investigación, Facultad de Odontología, Universidad Nacional Autónoma de México. Ciudad de México; México.

3. Laboratorio de Bioquímica, Microbiología y Patología. Facultad de Estomatología, Universidad Autónoma de San Luis Potosí. San Luis Potosí, SLP; México.

Autor para correspondencia: Dr. Florencio Rueda Gordillo - gordillo@correo.uady.mx

Recibido: 1-|II-2018

Aceptado: 20-III-2018

Publicado Online First: 3-IV-2018

DOI: https://doi.org/10.15517/ijds.v0i0.32882

\section{ABSTRACT}

Candida albicans is the etiological agent most frequently associated with oral candidiasis in human immunodeficiency virus (HIV) carriers. Strain typification is important to disease epidemiology, particularly with simple, low-cost methodologies such as resistotyping. The present study was designed to use resistotyping to identify possible phenotypic differences between $C$. albicans strains isolated from the oral cavity of HIV+ and HIV-seronegative patients. Analyses were run using resistotyping (boric acid, cetrimide, sodium periodate, sodium selenite and silver nitrate) to identify phenotypical differences between $C$. albicans. Descriptive statistics was performed. Of the 149 clones isolated from HIV+ patients the most frequent (47.0\%) resistotype was ABCDE. The most frequent resistotype $(64.8 \%)$ in the 74 clones from HIV-seronegative patients was --CDE. Phenotypic differences were identified between the strains isolated from each group. HIV+ patients exhibited greater strain diversity. Although it has limitations, resistotyping effectively identified differences between $C$. albicans strains.

\section{KEYWORDS}

Candida; Candida albicans; HIV; Carriers; Resistotyping; Epidemiology. 


\section{RESUMEN}

Candida albicans es el agente etiológico más frecuentemente asociado con la candidiasis oral en portadores del virus de la inmunodeficiencia humana $(\mathrm{VIH})$. La tipificación de la cepas es importante para conocer la epidemiología de la enfermedad, particularmente con metodologías simples y de bajo costo, como la resistotipificación. El presente estudio fue diseñado para identificar posibles diferencias fenotípicas por el método de resistotipificación entre cepas de $C$. albicans aisladas de la cavidad oral de pacientes $\mathrm{VIH}+$ y seronegativos. Se realizó estadística descriptiva. Los análisis se realizaron utilizando resistotipificación (ácido bórico, cetrimida, peryodato de sodio, selenito de sodio y nitrato de plata) para identificar diferencias fenotípicas entre C. albicans. De las 149 clonas aisladas de pacientes $\mathrm{VIH+}$, el resistotipo más frecuente (47.0\%) fue ABCDE. El resistotipo más frecuente (64.8\%) en las 74 clonas de pacientes seronegativos al VIH fue --CDE. Se identificaron diferencias fenotípicas entre las cepas aisladas de cada grupo. Los pacientes VIH + exhibieron una mayor diversidad de cepas. Aunque tiene limitaciones, la resistotipificación identificó de manera efectiva las diferencias entre las cepas de $C$. albicans.

\section{PALABRA CLAVE}

Candida; Candida albicans; VIH; Portadores; Resistotipificación; Epidemiología.

\section{INTRODUCTION}

Oral candidiasis (OC) has been closely linked to human immunodeficiency virus (HIV) infection since the pandemic began $(1,2)$. It has become an important diagnostic and prognosis parameter, as well as a marker of the success of highly active antiretroviral therapy $(3,4)$.

Extensive research has been done on $\mathrm{OC}$, and prophylactic treatments developed and implemented for treatment eradication, but it continues to be the most frequent opportunistic oral infection in HIV + patients, regardless of treatment with highly active antiretroviral therapy $(4,5)$.

Candida species, mainly C. albicans, are the causal agents of OC. Normally commensal dimorphic fungi, under specific local and systemic circumstances they can become pathogens $(6,7)$. The Candida species that colonize the oral cavity of HIV+ subjects exhibit greater antimycotic treatment resistance than strains from HIV-seronegative subjects. Resistance to antimycotic drugs is considered an important risk factor contributing to antimycotic resistance and consequent development of deep mycoses and candidemia (8).

Although C. albicans has a clonal mode of reproduction, phenotypic and genotypic traits can distinguish between strains (9). Strain-typing techniques have been developed to generate epidemiological data on C. albicans. These describe the behavior of different strains in distinct patient groups, thus identifying associations between genotypes and phenotypical traits, mainly antibiotic resistance and mechanisms of pathogenicity (9-13).

Genotype and phenotype variation in Candida species is a possible cause for increased antifungal resistance with consequent treatment failure and persistent infection. This suggests that oral candidiasis in HIV+ patients may be caused by different clones of the same species $(12,14)$. Little data is available on the presence of $C$. albicans clones with different resistance profiles colonizing the oral cavity of HIV+ subjects. In addition, it is still under debate if certain C. albicans strains exhibit variation in their virulence capabilities. 
The objective of this study was to use resistotyping to identify possible phenotypic differences between $C$. albicans strains isolated from the oral cavity of HIV+ and HIV-seronegative patients.

\section{METHODS}

\section{ETHICS STATEMENT}

The research protocol was approved by the bioethics committee of the Faculty of Dentistry of the Autonomous University of Yucatan (Universidad Autónoma de Yucatán [UADY]) (code FOCAI 04/02). It was classified as minimal risk in accordance with the Health Research Regulation, Article 17, General Health Law, Health Department, Government of Mexico.

\section{STRAIN ISOLATION AND RECOVERY}

A total of 92 consecutive clinical isolates of oral C. albicans strains were obtained from oral swabs subsequently frozen at $-80^{\circ} \mathrm{C}$ in heart infusion broth (Becton Dickinson, Mexico) containing 10\% glycerol (Sigma-Aldrich, USA). Isolates were collected from 37 healthy subjects ( $\geq 21$ years old) lacking clinical lesions indicating any clinical form of oral candidiasis, and from 55 HIV + patients $(>18-<50$ years old) in the O'Horan General Hospital, Merida, Yucatan, Mexico. Inclusion criteria for the HIV+ patients were that they must have been asymptomatic for any clinical form of oral candidiasis at the time of sampling, and not have received any antifungal or antibacterial treatment at least six months prior to oral examination.

Strains were sown on CHROMagar Candida (Becton Dickinson Microbiology Systems, USA) and incubated at $37^{\circ} \mathrm{C}$ for $48 \mathrm{~h}$. Isolates were identified by standard morphology.

MOLECULAR IDENTIFICATION

\section{DNA EXTRACTION}

Strains were grown on Sabouraud dextrose agar (SDA) (Becton Dickinson and Company, USA) for 48 hours at $37^{\circ} \mathrm{C}$, suspended in $500 \mu \mathrm{L}$ sterile distilled water, heated for $15 \mathrm{~min}$ at $95^{\circ} \mathrm{C}$ and then immediately frozen at $-70^{\circ} \mathrm{C}$ for 15 min. After thawing to room temperature samples were centrifuged for $5 \mathrm{~min}$ at $16,000 \times \mathrm{g}$, the supernatant placed in a sterile Eppendorf tube and stored at $-20^{\circ} \mathrm{C}$ until analysis $(6,15)$.

\section{PCR}

Two pairs of oligonucleotides (Invitrogen, USA) were simultaneously used in each PCR test: the first pair, specific to C. albicans, amplifies a $175 \mathrm{bp}$ fragment of the 25S rRNA gene: CAL5 (5'-TGTTGCTCTCTCGGGGGCGGCCG-3') and NL4CAL (5'-AAGATCATTATGCCAACATCCTAGGTA/TAA-3'). The second pair, present in all Candida species, amplifies a $610 \mathrm{bp}$ fragment of the 25S rRNA gene: RNAF (5'-GCATATCAATAAGCGGAGGAAAAG-3') and RNAR (5'-GGTCCGTGTTTCAAGACG-3'). PCR was done following Yang et al. (16) as described in Hernández-Solís et al. (11).

\section{RESISTOTYPING}

Resistogram biotyping of $C$. albicans strains was done following the McCreight and Warnock method as modified by Nakamura et al. (17). Briefly, stock solutions of boric acid, cetrimide, sodium periodate and sodium selenite (Sigma-Aldrich, 
USA) were prepared at a $20 \mathrm{mg} / \mathrm{mL}$ concentration. A silver nitrate (Sigma-Aldrich, USA) stock solution was prepared at a $2 \mathrm{mg} / \mathrm{mL}$ concentration.

The resistance profile was assessed based on different concentration series of each stock solution added to SDA: boric acid 1.15, 1.3, 1.45 and $1.6 \mathrm{mg} / \mathrm{mL}$; cetrimide $0.06,0.08,0.1$ and $0.12 \mathrm{mg} / \mathrm{mL}$; silver nitrate $0.0075,0.01,0.0125$ and $0.015 \mathrm{mg} / \mathrm{mL}$; sodium periodate $0.01,0.02$, 0.03 and $0.04 \mathrm{mg} / \mathrm{mL}$; and sodium selenite 0.1 , 0.2, 0.3 and $0.4 \mathrm{mg} / \mathrm{mL}$. Candida albicans (5 $\mu \mathrm{L}$ CFU), previously incubated for $24 \mathrm{~h}$ at $37^{\circ} \mathrm{C}$ and with an optical density ranging from 0.45 to 540 $\mathrm{nm}$, were inoculated onto the agar plates containing one of the chemical reagents and incubated for $40 \mathrm{~h}$ at $37^{\circ} \mathrm{C}$.

Resistance was tested using a concentration for each stock solution that had exhibited clear differentiation between the studied strains: 0.3 $\mathrm{mg} / \mathrm{mL}$ for sodium selenite; 1.6 for boric acid; 0.6 for cetrimide; 0.03 for sodium periodate; and 0.015 for silver nitrate (Table 1). Growth patterns were described following the criteria suggested by Khan et al. (18): confluent growth (resistance) with capital letter identifying reagent; non-confluent growth (sensitivity) with lowercase letter; and absence of growth indicated by a hyphen (-).

Table 1. Chemical inhibitor codes and concentrations used in resistotyping technique.

\begin{tabular}{ccc}
\hline $\begin{array}{c}\text { Chemical } \\
\text { inhibitor }\end{array}$ & Code & $\begin{array}{c}\text { Concentration } \\
(\mathbf{m g} / \mathbf{m L})\end{array}$ \\
\hline Sodium selenite & $\mathrm{A}$ & 0.3 \\
Boric acid & $\mathrm{B}$ & 1.6 \\
Cetrimide & $\mathrm{C}$ & 0.06 \\
Sodium periodate & $\mathrm{D}$ & 0.03 \\
Silver nitrate & $\mathrm{E}$ & 0.015 \\
\hline
\end{tabular}

\section{STATISTICAL ANALYSIS}

Descriptive statistics and possible associations between resistotype profiles and any study group were identified using a X2 test at a 95\% confidence level ( $p<0.05, \mathrm{Cl} 95 \%$ ) in the Statgraphics plus 5.1 software.

\section{RESULTS}

Control group. Thirty-seven C. albicans isolates were collected from the HIV-seronegative patients. From these, 74 clones were obtained (2 clones per strain) and seven different resistotypes identified (Table 2). The most frequent $(n=48$ clones; 64.8\%) resistotype profile was --CDE, followed by -bCDE $(n=8 ; 10.8 \%)$ and ---DE $(n=6$ cases; $8.1 \%$ ). One strain in this study group had two clones with different resistotype profiles.

Table 2. Resistotype patterns of $C$. albicans isolated from HIV-seronegative patients.

\begin{tabular}{ccc}
\hline Resistotype & Distribution & $\%$ \\
\hline --CDE & 48 & 64.8 \\
-bCDE & 8 & 10.8 \\
---DE & 6 & 8.1 \\
-b-d- & 4 & 5.4 \\
--cDE & 4 & 5.4 \\
a-CDe & 3 & 4.1 \\
-bcDe & 1 & 1.4 \\
Total & $\mathbf{7 4}$ & $\mathbf{1 0 0 . 0}$ \\
\hline
\end{tabular}

$\mathrm{HIV}+$ group. Three clones were obtained from each of the $55 \mathrm{C}$. albicans isolates from this group. Sixteen clones were lost during processing, leaving 149 clones to determine the resistotypes. Eleven different resistotype profiles were identified in this study group. The most frequent $(n=70$; 
47\%) was ABCDE, followed by A-CDE ( $n=37$; $24.9 \%)$ and $--\operatorname{CDE}(n=14 ; 9.4 \%)$. Twenty oral $C$. albicans strains were identified with two different resistotype profiles. The remaining strains had clones with the same resistotype profile (Table 3).

The frequency of the serotype --CDE was significantly higher in the HIV-seronegative group (64.8\% versus $9.4 \%, p<0.05)$.

Table 3. Resistotype patterns of $C$. albicans isolated from HIV+ patients.

\begin{tabular}{ccc}
\hline Resistotype & Distribution & \% \\
\hline ABCDE & 70 & 47.0 \\
A-CDE & 37 & 24.9 \\
--CDE & 14 & 9.4 \\
-BCDE & 13 & 8.7 \\
aBCDE & 5 & 3.4 \\
AB-DE & 2 & 1.3 \\
abCDE & 2 & 1.3 \\
-BC-- & 2 & 1.3 \\
--C-- & 2 & 1.3 \\
a-CDE & 1 & 0.7 \\
$--C-E$ & 1 & 0.7 \\
Total & $\mathbf{1 4 9}$ & $\mathbf{1 0 0 . 0}$ \\
\hline
\end{tabular}

\section{DISCUSSION}

Candida strain pathogenicity has been correlated to certain resistotypes (19). Variations in $C$. albicans clone biotype are known to exist in recurrent oral candidiasis in HIV+ patients $(17,20)$. Antifungal therapy can lead to replacement of an initial biotype by a new one, even one resistant to antifungal drugs. Though infrequent, shifts in the resistogram biotypes of oral $C$. albicans isolates may also occur to a certain extent in normal subjects (17).

Based on this phenomenon it is possible that differences may be linked to selection of a more virulent switched phenotype, or that a switched phenotype of the same strain can exhibit variations in virulence in response to changing environmental conditions $(18,21)$.

This being the case, $C$. albicans populations are mainly clonal in origin with gene content being apparently constant and stable between strains $(9,22)$. Phenotypic differences between C. albicans strains are therefore probably due mainly to changes in expression levels of associated genes, and/or minimal modifications in their sequences, which may influence variations in the function of their encoded proteins (9). Determining if changes in genetic expression are a possible cause of the presence of different $C$. albicans strains in the oral cavity of HIV + patients is beyond the scope of the present study and provides ample opportunity for future research. This will need to focus on identifying what factors are associated with changes in C. albicans phenotypes and biotypes, concentrating on these strains' intergenic regions and protein coding sequences (9).

Resistotype --C-- is reported to be the most common of the highly pathogenic C. albicans isolates (23). This does not coincide with the present results in which only two strains exhibited this resistotype; the rarity of --C-- resistotypes has been reported elsewhere (23). In a study of sixteen different resistograms from 198 oral isolates from 22 normal subjects (24), it was found that a particular strain tends to persist in the oral cavity of normal subjects although some changes can occur in these $C$. albicans biotypes. Differences in oral colonization by Candida species may be strongly influenced by ethnic, geographical and sociodemographic factors $(19,25,26)$.

A broad range of fungi-typing techniques currently exist with variations in throughput, cost, processing time and discriminatory power. What method is chosen will depend largely on the epidemiological data needed and available laboratory infrastructure $(10,12,27)$. Several 
technologies are currently available for biotyping and genotyping of $C$. albicans strains, molecular methods being the most precise methods for yeast biotyping (9,28-30). However, molecular biology methods are more expensive than phenotypic methods and are often only available in research or epidemiological reference laboratories $(19,30)$. Phenotyping methods such as auxonotyping, enzymotyping and resistotyping may be easy to run but do not have the discriminatory power of molecular methods $(19,29,31)$. Recurrent $C$. albicans isolates have been shown to exhibit a high frequency of morphological variation that is not related to genomic DNA fingerprinting (32).

The resource limitations of routine laboratories can make genotyping unfeasible, and morphotyping tests more promising $(18,19)$. However, discrimination between strains and results reproducibility require molecular typing methods to compare and confirm results. Most genotypic methods are expensive and involve highly specific infrastructure, as well as highly trained laboratory staff. This is a vital concern in developing and undeveloped countries, which have the highest HIV+/AIDS prevalence, since it prevents use of these highly specific techniques for routine strain identification. The resistotyping method used in the present study is an easy-torun, comparatively inexpensive method applicable to all $C$. albicans strains. It is a near ideal system in developing countries for phenotypic and genotypic identification of Candida strains since it allows for testing a large number of isolates, provides rapid results, involves relatively inexpensive procedures, and can be automated.

The usefulness of resistotyping for phenotypic discrimination of $C$. albicans strains is well known $(18,23,31)$, as are the problems of using phenotypic tests, such as lengthy time requirements, difficulty in automating and inaccurate strain identification (33). The resistotype technique has been successful in identifying different $C$. albicans strains from areas other than the oral cavity. It has also been used to identify four different $C$. albicans resistotypes (-B-F- was the most common) from the respiratory tract of TB-positive and TB-negative patients (34), and to identify C. albicans resistotypes from feces and vaginal mucus (A-C-F-, ABC-F- and A- -F- were the most frequent) (23). One promising approach for improving results accuracy is to use different analyses in conjunction (e.g. resistograms in addition to an API system, or Odds and Abbott's method) to increase discriminatory capacity beyond what each technique can offer individually $(18,31)$.

\section{CONCLUSIONS}

In this study, we have demonstrated the differences between strains isolated from HIV+ and seronegative patients. Resistotyping is easy to perform in laboratories with lower economic resources, and useful for epidemiological purposes.

\section{FOOTNOTE}

\section{FUNDING/SUPPORT}

This study was supported in part by PADECCA 2015 and PRODEP.

\section{CONFLICT OF INTEREST}

The authors declare no conflict of interest.

\section{REFERENCES}

1. Egusa H., Soysa N. S., Ellepola A. N., Yatani H., SamaranayakeL.P. Oral candidosis inHIVinfected patients. Curr HIV Res. 2008; 6 (6): 485-99. doi: 10.2174/157016208786501445. [PubMed: 18991614]

2. Askinyte D., Matulionyte R., Rimkevicius A. Oral manifestations of HIV disease: A review. Stomatologija. 2015; 17 (1): 21-8. [PubMed: 26183854]. 
3. Gaitán-Cepeda L. A., Martínez-González M., Ceballos-Salobreña A. Oral candidosis as a clinical marker of immune failure in patients with HIV/AIDS on HAART. AIDS Patient Care STDS. 2005; 19 (2):70-7. doi: 10.1089/ apc.2005.19.70. [PubMed: 15716638]

4. Taiwo O. O., Hassan Z. The impact of highly active antiretroviral therapy (HAART) on the clinical features of HIV - related oral lesions in Nigeria. AIDS Res Ther. 2010;7:19. doi: 10.1186/1742-6405-7-19. [PubMed: 20579347]

5. Gaitán-Cepeda L. A., Sánchez-Vargas O., Castillo N. Prevalence of oral candidiasis in HIV/AIDS children in highly active antiretroviral therapy era. A literature analysis. Int J STD AIDS. 2015; 26 (9): 625-32. doi: 10.1177/0956462414548906. [PubMed: 25156369]

6. Hernández-Solís S. E., Rueda-Gordillo F., Flota-Alcocer A. D., Aguilar-Ayala F. J., Rodríguez-Fernández M. del S., LamaGonzález EM. Influence of orthodontic appliances on the occurrence of Candida spp. in the oral cavity. Rev Chilena Infectol. 2016; 33 (3): 293-7. doi: 10.4067/S071610182016000300007. [PubMed: 27598278]

7. Mayer F. L., Wilson D., Hube B. Candida albicans pathogenicity mechanisms. Virulence. 2013; 4 (2): 119-28. doi: 10.4161/viru.22913

8. Vazquez J. A. Optimal management of oropharyngeal and esophageal candidiasis in patients living with HIV infection. HIV AIDS (Auckl). 2010; 2: 89-101. doi: 10.2147/HIV.S6660

9. Thewes S., Moran G. P., Magee B. B., Schaller M., Sullivan D. J., Hube B. Phenotypic screening, transcriptional profiling, and comparative genomic analysis of an invasive and non-invasive strain of Candida albicans. BMC Microbiol. 2008; 8: 187. doi: 10.1186/1471-2180-8-187. [PubMed: 18950481]

10. Choo K. H., Lee H. J., Knight N. J., Holmes A. R., Cannon R. D. Multilocus sequence typing (MLST) analysis of Candida albicans isolates colonizing acrylic dentures before and after denture replacement. Med Mycol. 2017; 55 (6): 673-9. doi: 10.1093/mmy/ myw128. [PubMed: 27915298]

11. Hernández-Solís S. E., Rueda-Gordillo F., Rojas-Herrera R. A. Proteinase activity in Candida albicans strains isolated from the oral cavity of immunocompromised patients, with oral candidiasis and in healthy subjects. Rev Iberoam Micol. 2014; 31 (2): 137-40. doi: 10.1016/j.riam.2013.09.003. [PubMed: 24071641]

12. Bitar I., Khalaf R. A., Harastani H., Tokajian S. Identification, typing, antifungal resistance profile, and biofilm formation of Candida albicans isolates from Lebanese hospital patients. Biomed Res Int. 2014; 2014: 931372. doi: 10.1155/2014/931372. [PubMed: 24982915]

13. Arce-Gil Z. L., Silva V., Silva V. Especies de Candida aisladas de muestra vaginal y orina de pacientes oncológicos del Instituto Nacional de Enfermedades Neoplásicas (INEN), Lima, Perú. Genotipificación de Candida albicans. Rev Cuerpo Med HNAAA. 2015; 8 (3): 168-73.

14. González H., Da Silva I., Reyes E. Caracterización molecular de cepas de Candida albicans aisladas de candidiasis oral en personas VIH positivo. Cienc Trab. 2006; 8 (22): 172-6.

15. De Baere T., Claeys G., Swinne D., Verschraegen G., Muylaert A., Massonet C., et al. Identification of cultured isolates of clinically important yeast species using fluorescent fragment length analysis of the amplified internally transcribed rRNA spacer 2 region (ITS2). BMC Microbiol. 2002;2:21. doi: 10.1186/1471-2180-2-21. [PubMed: 12139769]

16. Yang C. W., Barkham T. M., Chan F. Y., Wang Y. Prevalence of Candida species, including Candida dubliniensis, in Singapore. J 
Clin Microbiol. 2003; 41 (1): 472-4. doi: 10.1128/JCM.41.1.472-474.2003. [PubMed: 12517898]

17. Nakamura K., Ito-Kuwa S., Nakamura Y., Aoki S., Vidotto V., Sinicco A. Resistogram typing of oral Candida albicans isolates from normal subjects in three successive trials. Rev Iberoam Micol. 1998; 15 (1): 19-21. [PubMed: 17655398].

18. Khan Z. U., Chandy R., Metwali K. E. Candida albicans strain carriage in patients and nursing staff of an intensive care unit: A study of morphotypes and resistotypes. Mycoses. 2003; 46 (11-12): 479-86. doi: 10.1046/j.0933-7407.2003.00929.x. [PubMed: 14641621]

19. Giammanco G. M., Lopes M. M., Coimbra R. S., et al. Value of morphotyping for the characterization of Candida albicans clinical isolates. Mem Inst Oswaldo Cruz. 2005; 100 (5): 483-90. doi: /S007402762005000500007. [PubMed: 16184225]

20. Bruatto M., Vidotto V., Marinuzzi G., Raiteri R., Sinicco A. Candida albicans biotypes in human immunodeficiency virus type 1-infected patients with oral candidiasis before and after antifungal therapy. J Clin Microbiol. 1991; 29 (4): 726-30. [PubMed: 1679764].

21. Figueiral M. H., Fonseca P., Lopes M. M., Pinto E., Pereira-Leite T., Sampaio-Maia B. Effect of denture-related stomatitis fluconazole treatment on oral Candida albicans susceptibility profile and genotypic variability. Open Dent J. 2015; 9: 46-51. doi: 10.2174/1874210601509010046. [PubMed: 25674171]

22. Sampaio P., Gusmao L., Correia A., Alves C., Rodrigues A. G., Pina-Vaz C., et al. New microsatellite multiplex PCR for Candida albicans strain typing reveals microevolutionary changes. J Clin Microbiol. 2005; 43 (8): 3869-76. doi:
10.1128/JCM.43.8.3869-3876.2005. [PubMed: 16081924]

23. Hunter P. R., Fraser C. Use of modified resistogram to type Candida albicans isolated from cases of vaginitis and from faeces in the same geographical area. J Clin Pathol. 1987; 40 (10): 1159-61. doi: 10.1136/jcp.40.10.1159. [PubMed: 3316288]

24. McCreight M. C., Warnock D. W., Watkinson AC. Prevalence of different strains of Candida albicans in patients with dentureinduced stomatitis. Sabouraudia. 1984; 22 (1): 83-85. doi: 10.1080/00362178485380131. [PubMed: 6367101]

25. Menezes R. de P., Borges A. S., Araujo L. B., Pedroso Rdos S., Roder D. V. Related factors for colonization by Candida species in the oral cavity of HIV-infected individuals. Rev Inst Med Trop Sao Paulo. 2015; 57 (5): 4139. doi: 10.1590/S0036-46652015000500008. [PubMed: 26603229]

26. Pongsiriwet S., Iamaroon A., Sriburee P., Pattanaporn K., Krisanaprakornkit S. Oral colonization of Candida species in perinatally HIV-infected children in northern Thailand. J Oral Sci. 2004; 46 (2): 101-5. doi: 10.2334/ josnusd.46.101. [PubMed: 15287543]

27. Hadrich I., Ranque S. Typing of fungi in an outbreak setting: Lessons learned. Curr Fungal Infect Rep. 2015; 9 (4): 314-23. doi: 10.1007/s12281-015-0245-y

28. Nyazika T. K., Robertson V. J., Nherera B., Mapondera P. T., Meis J. F., Hagen F. Comparison of biotyping methods as alternative identification tools to molecular typing of pathogenic Cryptococcus species in sub-Saharan Africa. Mycoses. 2016; 59 (3): 151-6. doi: 10.1111/myc.12444. [PubMed: 26661484]

29. Gil-Lamaignere C., Roilides E., Hacker J., Muller F. M. Molecular typing for fungi--a critical review of the possibilities and limitations of currently and future methods. Clin Microbiol 
Infect. 2003; 9 (3): 172-85. doi: 10.1046/j.14690691.2003.00649.x. [PubMed: 12667249]

30. Saghrouni F., Ben Abdeljelil J., Boukadida J., Ben Said M. Molecular methods for strain typing of Candida albicans: A review. J Appl Microbiol. 2013; 114 (6): 1559-74. doi: 10.1111/jam.12132. [PubMed: 23311504]

31. Otero L., Vázquez F., Palacio V., Vázquez S., Carreño F., Méndez F. J. Comparison of seven phenotyping methods for Candida albicans. Eur J Epidemiol. 1995; 11 (2): 221-4. doi: 10.1007/BF01719492. [PubMed: 7672080]

32. O'Connell B., Coleman D. C., Bennett D., Sullivan D., McCann S. R., Keane C. T. An epidemiological study of Candida species infection in cancer patients using genetic fingerprinting and morphotyping. J Hosp Infect. 1995;31 (3): 211-7. doi: 10.1016/01956701(95)90068-3. [PubMed: 8586790]

33. Buzzini P., Turchetti B., Vaughan-Martini A. E. The use of killer sensitivity patterns for biotyping yeast strains: The state of the art, potentialities and limitations. FEMS Yeast Res. 2007; 7 (6): 749-60. doi: 10.1111/j.15671364.2007.00238.x. [PubMed: 17425671]

34. Prasobh K. K., Udhaya V., Sarayu Y. L. Resistotyping of Candida albicans isolated from sputum samples of patients attending TB clinics in and around Chidambaram. Rec Res Sci Tech. 2009; 1 (4): 180-3. 